\title{
Isolation, molecular characterization and growth-promotion activities of a cold tolerant bacterium Pseudomonas sp. NARs9 (MTCC9002) from the Indian Himalayas
}

\author{
PANKAJ K. MISHRA ${ }^{1, *}$, SMITA MISHRA ${ }^{1}$, SHEKHAR C. BISHT $^{1}$, \\ G. SELVAKUMAR ${ }^{1}$, S. KUNDU ${ }^{2}$, J. K. BISHT ${ }^{1}$ and HARI SHANKAR GUPTA ${ }^{1}$ \\ ${ }^{1}$ Vivekananda Institute of Hill Agriculture, (Indian Council of Agricultural Research) Almora-263601, \\ Uttarakhand, India \\ ${ }^{2}$ Indian Institute of Soil Science, (Indian Council of Agricultural Research) Bhopal, M. P., India
}

\begin{abstract}
A bacterium that grows and expresses plant growth promotion traits at $4^{\circ} \mathrm{C}$ was isolated from the rhizospheric soil of Amaranth, cultivated at a high altitude location in the North Western Indian Himalayas. The isolate was Gram negative and the cells appeared as rods $(2.91 \times 0.71 \mu \mathrm{m}$ in size $)$. It grew at temperatures ranging from 4 to $30^{\circ} \mathrm{C}$, with a growth optimum at $28^{\circ} \mathrm{C}$. It exhibited tolerance to a wide $\mathrm{pH}$ range $(5-10$; optimum 8.0 ) and salt concentrations up to $6 \%$ (wt/vol). Although it was sensitive to Rifampicin ( $20 \mu \mathrm{g} \mathrm{ml}{ }^{-1}$ ), Gentamicin (G $3 \mu \mathrm{g} \mathrm{ml}^{-1}$ ), and Streptomycin $\left(\mathrm{S} 5 \mu \mathrm{g} \mathrm{ml}^{-1}\right.$ ), it showed resistance to higher concentrations of Ampicillin (A $500 \mu \mathrm{g} \mathrm{ml}^{-1}$ ), Penicillin $\left(\mathrm{P} 300 \mu \mathrm{g} \mathrm{ml}^{-1}\right.$ ), Polymixin B sulphate $\left(\mathrm{Pb} 100 \mu \mathrm{g} \mathrm{ml} \mathrm{m}^{-1}\right.$ ) and Chloramphenicol (C $200 \mu \mathrm{g} \mathrm{ml}^{-1}$ ). The $16 \mathrm{~S}$ rRNA sequence analysis revealed maximum identity with Pseudomonas lurida. The bacterium produced Indole Acetic Acid (IAA) and solubilizes phosphate at 4, 15 and $28^{\circ} \mathrm{C}$. It also retained its ability to produce rhamnolipids and siderophores at $15^{\circ} \mathrm{C}$. Seed bacterization with the isolate enhanced the germination, shoot and root lengths of thirty-day-old wheat seedlings by 19.2 , $30.0 \& 22.9 \%$ respectively, as compared to the un-inoculated controls.
\end{abstract}

Key terms: Cold tolerant, Pseudomonas lurida, 16S rRNA gene, Nutrient uptake, Plant growth promotion.

\section{INTRODUCTION}

More than $80 \%$ of the earth's biosphere is cold and exposed to temperatures below $5^{\circ} \mathrm{C}$ throughout the year. Vast tracts of soils across the world remain permanently frozen for the better part of the year, with an intermittent thawing period in summer (Hebraoud and Potier, 1999). Since temperature is a major factor that determines survival and growth of nearly all living species, changes in temperature away from the optimum, drastically affects the productivity of an ecosystem. Low temperatures, coupled with frost, are major constraints for crop production since plant growth and overall productivity generally decline under chilling conditions (Kumar et al., 2005). Since microorganisms are an integral part of any ecosystem, interest has been renewed in the nature and properties of microbes that play a major role in nutrient cycling in cold ecosystems (Häggblom and Margesin, 2005).

Based on their preference for cold temperatures, microbes are classified as psychrophiles (cold-loving) and psychrotolerant (cold tolerant). Psychrophiles colonize permanently cold habitats, such as polar regions, high altitudes, and the deep sea, and grow at temperatures ranging from sub zero to

Corresponding Author: Pankaj K. Mishra, Vivekananda Institute of Hill Agriculture, (Indian Council of Agricultural Research), Almora-263601, Uttarakhand, India, Tel.: +91 9412589393, Fax: +91 5962 231539, Email: misrapank12@gmail.com 
$15^{\circ} \mathrm{C}$. Environments with periodic, diurnal, or seasonal temperature fluctuations (e.g., areas with continental climates with high summer and low winter temperatures) are favorable for the growth and proliferation of psychrotolerant (also termed coldtolerant or psychrotrophic) microorganisms, which grow over a wide temperature range from 4 to $42^{\circ} \mathrm{C}$ and usually grow optimally at temperatures above $20^{\circ} \mathrm{C}$ (Morita, 1975). In high altitude agro-ecosystems, where cold conditions are usually transitional in nature, psychrotolerant microbes are extremely important since they survive and retain their functionality in cold temperature conditions, while growing optimally at warmer temperatures.

With an increasing awareness about the need for location specific inoculants, to fully realize the benefits the bacterial inoculation, attempts are being made to isolate and utilize micro flora that are highly adapted specific climatic and soil conditions (Mishra et al., 2008). Since agricultural production in the Indian Himalayan Region (IHR) is to a large extent influenced by the low soil and atmospheric temperature conditions, especially during the winter months, it is imperative to harness cold adapted strains of rhizospheric bacteria that can positively influence plant growth and development and offset the negative influence of cold temperatures. The present investigation describes the cold tolerance and plant growth promotion abilities of a psychrotolerant bacterium Pseudomonas sp. NARs9 (MTCC9002) isolated from the rhizosphere of Amaranth, cultivated at a high altitude location in the North Western Indian Himalayas.

\section{METHODS}

Isolation of the cold tolerant bacterial strain from Amaranthus rhizosphere

The soil used for bacterial isolation was collected from the rhizosphere of Amaranth grown at a high altitude location [2509 meters above mean sea level (amsl)], of the Nainital District (2930' $\mathrm{N}$ and $79^{\circ} 30^{\prime} \mathrm{E}$ ) in the North Western Indian Himalayas. The average mean annual soil temperature of the sampling location varied from $-4^{\circ} \mathrm{C}$ to $18^{\circ} \mathrm{C}$. The rhizospheric soil adhering to the roots was collected in sterile containers and transported to the laboratory at $4 \pm 1^{\circ} \mathrm{C}$ and stored at the same temperature until further use. Serial dilutions of rhizospheric soil were prepared in $0.85 \%$ saline prepared in triple distilled water, and aliquots were individually plated on King's B (KB) and half strength nutrient agar (Hi-Media Laboratories, Pvt. Ltd., Mumbai, India) and incubated at $4{ }^{\circ} \mathrm{C}$. Bacterial colonies representative of the predominant morphological types present on the plates were selected and purified on the respective medium. Based on a preliminary screening assay for plant growth promotion traits, the isolate Pseudomonas sp. NARs9 was chosen for further intensive study. The cell culture of the isolate was deposited in the Microbial Type Culture Collection (MTCC), IMTECH, Chandigarh, India under the accession number MTCC 9002.

Characterization, identification and phylogenetic analysis

Pseudomonas sp strain NARs9 was maintained on King's B (KB) agar (HiMedia, Mumbai) medium containing $\left(\mathrm{g} \mathrm{l}^{-1}\right)$ : (peptone, $20 \mathrm{~g}$; $\mathrm{MgSO}_{4}, 1.5 \mathrm{~g} ; \mathrm{K}_{2} \mathrm{HPO}_{4}, 1.5 \mathrm{~g}$; glycerol, $10 \mathrm{ml}$; agar, $20 \mathrm{~g}$ and distilled water 1 l) (King et al. 1954). The $\mathrm{pH}$ was adjusted to $7.0 \pm 0.2$ with $1 \mathrm{~N} \mathrm{NaOH}$ before autoclaving. All the experiments were conducted after raising fresh cultures, for which $1 \mathrm{ml}$ from an overnight grown culture was inoculated in $50 \mathrm{ml}$ of $\mathrm{KB}$ broth. Phenotypic genus-level characterization of the isolate was carried out by subjecting the bacterial isolate to cultural (oxygen requirement), morphological (colony morphology and pigmentation), microscopic (Gram staining, cell shape, size and arrangement of cells), biochemical (utilization of 34 different carbon sources and enzyme activity) (Compant et al., 2005; Holt et al., 1994), and physiological characterizations (temperature, $\mathrm{pH}$, salt tolerance and antibiotic sensitivity) following standard procedures. The Intrinsic Antibiotic Resistance (IAR) pattern of the isolate Pseudomonas sp. 
NARs9 (MTCC9002) was determined using various concentrations of the antibiotics viz., Penicillin (P), Streptomycin (S), Bacitracin (B), Chloramphenicol (C), Ampicillin (A), Carbicillin $(\mathrm{Cb})$, Erythromycin (E), Polymyxin B sulphate $(\mathrm{Pb})$, Rifampicin (R) and Gentamycin $(G)$, on half strength Nutrient Agar (NA) plates supplemented with the desired concentration of the individual antibiotics. Logarithmic growth phase cultures were streaked on NA plates and incubated at $28 \pm 1^{\circ} \mathrm{C}$ for $24 \mathrm{~h}$. The appearance of visible growth within $24 \mathrm{~h}$ was taken as an indicator of resistance to the incorporated concentration of the antibiotic. The assay was replicated thrice to confirm the results. The growth pattern of the isolate was determined at three different temperatures viz., 4,15 , and $28^{\circ} \mathrm{C}$, by inoculating $5 \mathrm{ml}$ of an exponentially growing culture $\left(3.8 \times 10^{8}\right.$ cfu ml-1) in $100 \mathrm{ml}$ of the King's B broth (initial population $6.5 \mathrm{log} \mathrm{cfu} \mathrm{ml}^{-1}$ ), and estimating the cell population at $2 \mathrm{~h}$ intervals. The numerical values were $\log$ transformed and plotted against time.

Species level identification, based on 16S ribosomal RNA gene sequencing of the isolate, was performed at the Institute of Microbial Technology (IMTECH), Chandigarh, India, by using the universal primer $27 \mathrm{~F}$ primer on an ABI $3031 \times 1$ analyzer. The identity of the isolate was determined through a BLAST search. Nucleotide sequences were aligned using the CLUSTAL X 1.81 algorithm (Thompson et al., 1997). Phylogenetic and molecular evolutionary analyses were conducted using MEGA version 3.1 (Kumar et al., 2004). The phylogenetic tree was constructed by the neighbour-joining method (Saitou and Nei, 1987) using the distance matrix from the alignment. Distances were calculated using the Kimura method (Kimura, 1980). The GenBank accession number of the isolate is EU 195451.

Quantitative estimation of Indole Acetic Acid (IAA) production and phosphate solubilization

Quantitative estimation of IAA production and tri calcium phosphate (TCP) solubilization were carried out at three different incubation temperatures viz., 4, 15 and $28^{\circ} \mathrm{C}$. The colorimetric method of Gordon and Weber (1951) was used to quantify IAA production by the bacterium. Pseudomonas sp. strain NARs9 was grown overnight in $10 \mathrm{ml}$ of LB media, and $5 \mathrm{~mL}$ aliquots $\left(5.6 \times 10^{7} \mathrm{cfu} \mathrm{ml}^{-1}\right)$ was transferred into $145 \mathrm{ml}$ of LB media supplemented with $5 \mathrm{mM}$ L-trytophan (from a filter-sterilized $500 \mathrm{mM}$ stock prepared in ethyl alcohol; HiMedia, Mumbai) and incubated at 4, 15 and $28^{\circ} \mathrm{C}$ for $72 \mathrm{~h}$. At the end of the incubation period the bacterial cells were removed from the culture medium by centrifugation at $10,000 \mathrm{rpm}$ for $10 \mathrm{~min}$. One $\mathrm{ml}$ of the supernatant was mixed vigorously with $2 \mathrm{ml}$ of Salkowski's reagent $(2 \mathrm{ml} 0.5 \mathrm{M}$ ferric chloride and 100 $\mathrm{ml} \mathrm{35 \%} \mathrm{(w/w)} \mathrm{perchloric} \mathrm{acid)} \mathrm{and} \mathrm{allowed}$ to stand in the dark at room temperature for 25 min for color development. The absorbance was measured at $530 \mathrm{~nm}$ in a spectrophotometer (Specord 40, AnalytiK Jena, Germany). The concentration of IAA in culture supernatant was determined using a standard curve prepared with known concentrations of IAA (Hi Media India).

Quantitative estimation of $P$ solubilization was carried out by inoculating $1 \mathrm{ml}$ of bacterial suspension $\left(5.6 \times 10^{7} \mathrm{cfu} \mathrm{ml}^{-1}\right)$ in $50 \mathrm{ml}$ of the National Botanical Research Institute Phosphate (NBRIP) broth (Mehta and Nautiyal, 2001), in Erlenmeyer flasks $(150 \mathrm{ml})$, and incubating the flasks for 7 days. At the end of the incubation period the cell suspension was centrifuged at $10,000 \mathrm{rpm}$ for $10 \mathrm{~min}$. and the $\mathrm{P}$ content in the supernatant was spectrophotometrically estimated by the ascorbic acid method of Murphy and Riley (1962). All the experiments were repeated on three independent dates to confirm the results.

Qualitative measurement of siderophore and hydrocyanic acid ( $\mathrm{HCN})$ production

Siderophore and $\mathrm{HCN}$ production by the isolate were estimated qualititatively at three different incubation temperatures viz., 4,15 and $28^{\circ} \mathrm{C}$. Siderophore production was detected by the Chrome Azurol-S (CAS) assay (Schwyn and Neilands, 1987) in 100 
mm Petri dishes. Chrome azurol ' $S$ ' plates were spot inoculated with a loopful of actively growing bacterial culture ( $24 \mathrm{~h}$ old $)$ and observed daily for the formation of orange zones around the colonies was recorded. HCN production was assessed by the qualitative method of Bakker and Schippers (1987). The isolate was grown on King's B agar supplemented with glycine $(5.8 \mathrm{mM})$ in petri plates with lids fitted with a Whatman no. 1 filter paper previously soaked in saturated in picric acid solution (5 g picric acid and $25 \mathrm{~g} \mathrm{Na}_{2} \mathrm{CO}_{3}$ in 11 triple distilled water). The change in the color of the filter paper from yellow to dark brown was assessed visually depending on the intensity of the colour change.

\section{Evaluation of plant growth promoting ability of the isolate on wheat}

Evaluation of the plant growth promotion ability of the isolate on wheat seedlings was determined in non-sterile soil under glasshouse conditions. Seeds were bacterized as per standard procedure (Elliot and Lynch, 1984) with minor modifications. Surface sterilized seeds of wheat (cv. VL 829) were coated with a charcoal-based inoculant of the culture $\left(10^{8}\right.$ $\left.\mathrm{cfu}^{-1}\right)$. Control seeds were coated with sterile charcoal. Bacterized seeds were sown in cups (6.5-cm dia. and 10-cm depth) containing non sterile soil ( $\mathrm{pH}-6.8$, organic carbon - $0.6 \%$, available $\mathrm{N}-403 \mathrm{~kg} \mathrm{ha}^{-1}$, available $\mathrm{P}-15.2 \mathrm{~kg} \mathrm{ha}^{-1}$, available $\mathrm{K}-210$ $\mathrm{kg} \mathrm{ha}{ }^{-1}$, iron-10 mg kg-1) and placed in a temperature controlled growth chamber $\left\{16 / 8 \mathrm{~h} \mathrm{light/dark}\right.$ cycle (30 to $47 \mathrm{mEM}^{-2}$ $\left.\left.\min ^{-1}\right)\right\}$ at $18^{\circ} \mathrm{C}$ for 30 days. Thinning of seedlings was done 7 days after sowing and two seedlings per pot were maintained throughout the experimental period. The soil was moistened to $60 \%$ of its waterholding capacity. The treatments were arranged in a completely randomized design with ten replications. At the end of the experimental period, the plants were uprooted, washed under running water, and root and shoot lengths were measured. The plant biomass was dried at a constant temperature of $65^{\circ} \mathrm{C}$ and dry weights were recorded. The oven-dried samples were ground to pass through a $0.2 \mathrm{~mm}$ sieve for estimation of $\mathrm{N}$ content in a $\mathrm{CHN}$ analyser (CHN-O-Rapid Foss Heareus). After wet digestion of the plant samples, the $\mathrm{P}$ content was estimated by the ammonium molybdate method and the $\mathrm{K}$ content by flame photometry (Jackson, 1973). The nutrient uptake value was calculated from the nutrient content.

The effect of the bacterium on the germination of wheat seeds (var. VL 829) was determined by a paper roll towel assay. Surface sterilized seeds were soaked in a culture suspension of the bacterium $(5.6 \mathrm{x}$ $10^{7} \mathrm{cfu} \mathrm{ml}^{-1}$ ) for 30 minutes and air dried in a laminar hood under sterile conditions. Ten seeds were placed in an equidistant manner in a paper towel that was rolled and placed in a beaker containing 11 of sterile $0.25 \mathrm{x}$ nutrient solution (Broughton and Dilworth, 1971). Control seeds were soaked in sterile nutrient broth and placed in the same manner as mentioned above. The percent germination was recorded after seven days of incubation in the dark at $18^{\circ} \mathrm{C}$. Ten replicates each were maintained for the control and treatment.

\section{Statistical analysis}

The experimental data were analysed statistically according to Steel and Torrie (Steel and Torrie, 1980) and treatment means were compared at 5\% level of significance.

\section{RESULTS}

Pale white, translucent colonies of 2-3 mm diameter appeared on King's B agar after 34 days incubation at $4^{\circ} \mathrm{C}$. The colonies were entire, circular, convex, and smooth in appearance. Differential staining and microscopic examination revealed that the isolate was Gram negative. The cells appeared as rods (approximately $2.29 \mu \mathrm{m}$ (L) $\times 0.71 \mu \mathrm{m}(\mathrm{W})$, area-3.29 \pm 0.32 and $0.27 \mu \mathrm{m}$ diameter), arranged singly and were highly motile. The isolate was able to grow over a wide range of temperatures between $4-30^{\circ} \mathrm{C}$, but maximum growth was found to occur at $28^{\circ} \mathrm{C}$. It had a $\mathrm{pH}$ tolerance over the range 5-10 and could 
tolerate $\mathrm{NaCl}$ concentrations upto $6 \%$. It was positive for catalase, oxidase, citrate utilization, casein hydrolysis, ornithine and lysine decarboxylase activities. Positive carbon sources were glucose, malonate, galactose, D-arabinose, L-arabinose, xylose, melibiose, mannose, sucrose, and glucosamine. Although it was sensitive to Rifampicin $\left(20 \mu \mathrm{g} \mathrm{ml}^{-1}\right)$, Gentamicin $(3 \mu \mathrm{g}$

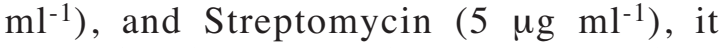
showed resistance to higher concentrations of Ampicillin $\left(500 \mu \mathrm{g} \mathrm{ml}^{-1}\right)$, Penicillin (300 $\left.\mu \mathrm{g} \mathrm{ml}{ }^{-1}\right)$, Polymxin B sulphate $\left(100 \mu \mathrm{g} \mathrm{ml}^{-}\right.$ $\left.{ }^{1}\right)$ and Chloramphenicol $\left(200 \mu \mathrm{g} \mathrm{ml} \mathrm{m}^{-1}\right)$. From the examination of the growth curve (Fig. 1), it is clear that the bacterium attained exponential growth before $24 \mathrm{~h}$ when incubated at 4 and $15^{\circ} \mathrm{C}$. Based on cultural characteristics, colony morphology, microscopic observations, biochemical, and physiological properties the isolate was identified as Pseudomonas sp. The $16 \mathrm{~S}$ ribosomal RNA gene sequence of the isolate had $99 \%$ identity with Pseudomonas lurida. The phylogenetic tree (Fig. 2) constructed using $16 \mathrm{~S}$ rRNA gene sequences of other related members of the
Pseudomonad group revealed that the isolate formed a close cluster with Pseudomonas lurida and while it was quite distinct from Pseudomonas syringae.

The different plant growth promotion traits of the isolate were determined at three different incubation temperatures (Table I). At $15^{\circ} \mathrm{C}$ the isolate was able to solubilize

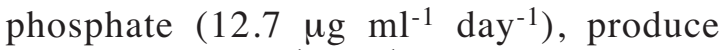
IAA $\left(13.1 \mu \mathrm{g} \mathrm{ml}^{-1} \mathrm{day}^{-1}\right)$ besides producing siderophores. It was interesting to observe that the isolate was able to retain its functional traits even at $4^{\circ} \mathrm{C}$, which was the lower temperature extreme for its growth, while higher values for all parameters were recorded at $28^{\circ} \mathrm{C}$. The plant growth promotion potential of Pseudomonas sp. strain NARs9 (MTCC9002) was determined by a pot culture assay under non-sterile soil conditions at sub-optimal temperatures. It was observed that the bacterized wheat seedlings recorded $19.2 \%$ higher seed germination, 30.0 and $22.9 \%$ higher shoot and root length respectively, as compared to the uninoculated control (Table II). A corresponding increase in the root and shoot biomass was also observed in

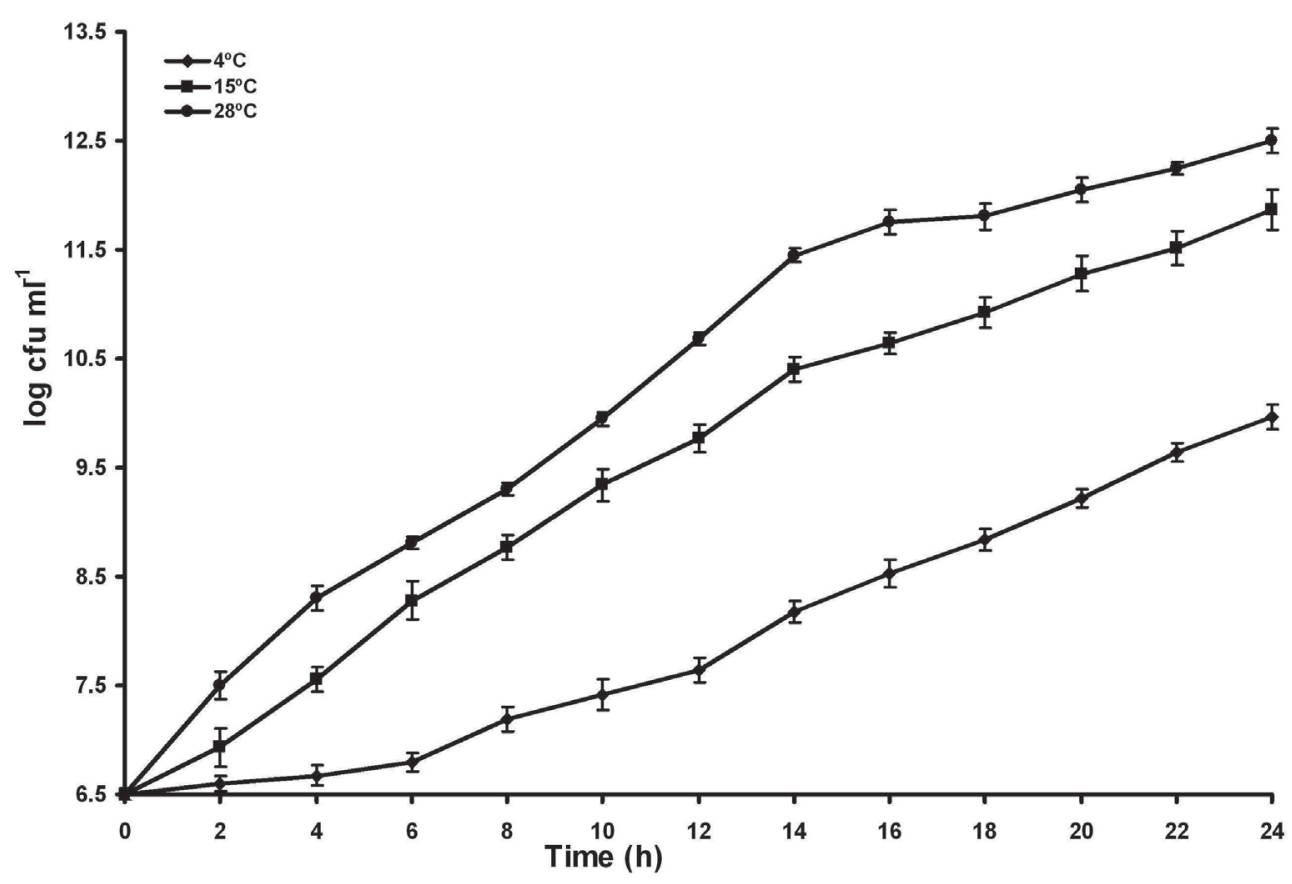

Figure 1: Growth curve of Pseudomonas sp. NARs9 (MTCC9002) at three different incubation temperatures. Bar represents the standard deviation (SD). 
bacterized seedlings. Seed bacterization resulted in greater enhancement of the root growth, as compared to the shoot growth. Besides enhanced root and shoot growth, an increase in chlorophyll a, chlorophyll b, total chlorophyll, total iron and physiologically available iron content was also recorded in the bacterized seedlings. Seed bacterization also increased the uptake $\mathrm{N}, \mathrm{P}$ and $\mathrm{K}$ by $11.9,21.0$ and $32.3 \%$ respectively over the uninoculated controls.

\section{DISCUSSION}

The beneficial effects of plant growth promoting rhizobacteria, particularly those belonging to the genus Bacillus or Pseudomonas, in enhancing growth and overall plant establishment is well established. This has been attributed to various mechanisms, such as providing fixed nitrogen to the host plant, production of phytohormones, solubilization of insoluble phosphates, production of metabolites, including antibiotics and siderophores (Compant et al., 2005). But inoculation of soil with such beneficial microorganisms may not result in significant effects unless the environment supports growth and survival of the introduced microorganisms. In this context the relevance of locally adapted strains of bio-inoculants gains paramount importance since most often the introduced strains fail to produce the desired effects of inoculation (Whipps, 2001).

The Indian Himalayas are a rich repository of cold tolerant bacteria of both agricultural and industrial importance.

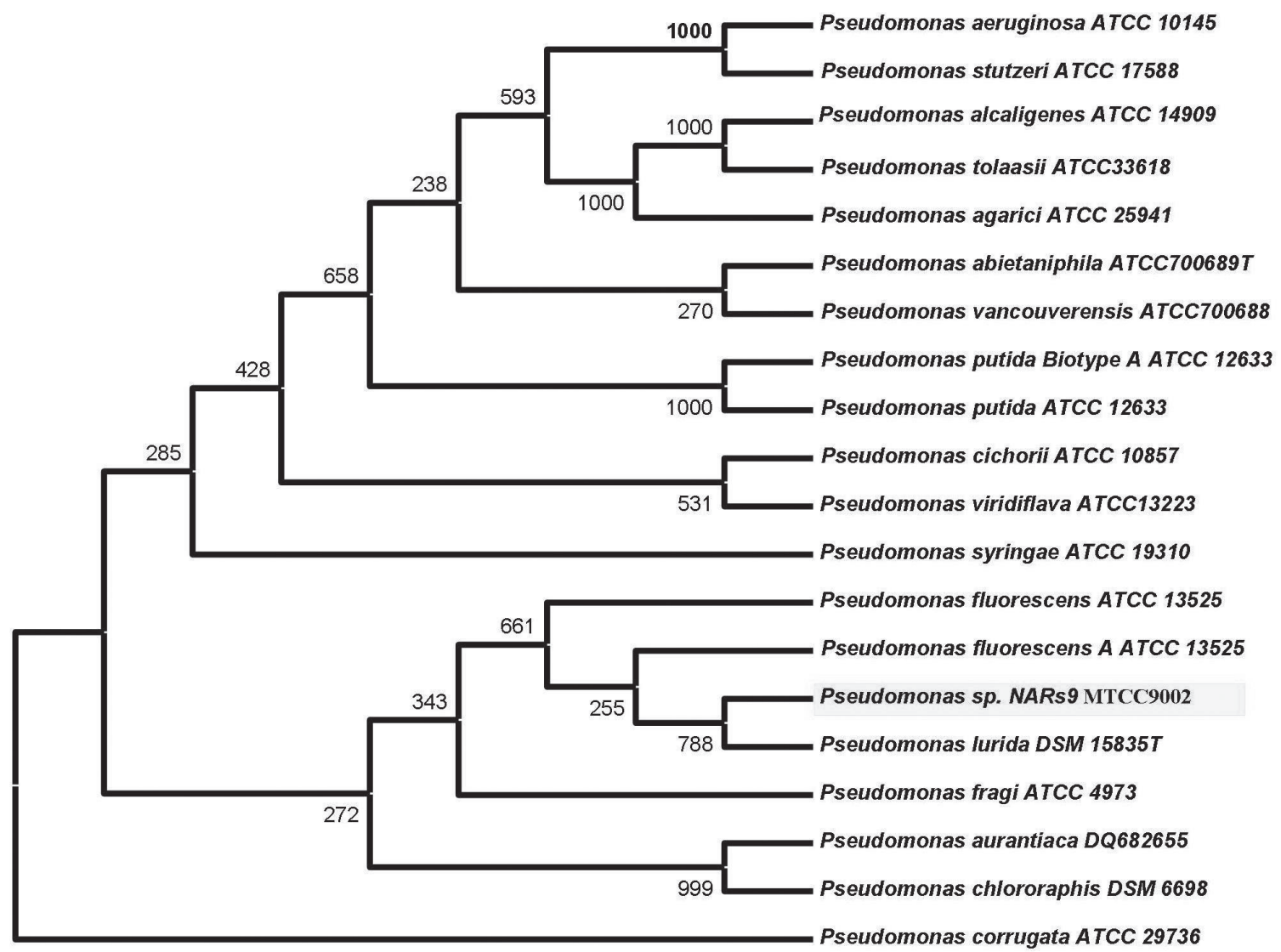

Figure 2: Phylogenetic tree showing relationships between Pseudomonas sp. NARs9 (MTCC9002) and other Pseudomonads. The bootstrap values $(\mathrm{n}=1000)$ are displayed at nodes. 
Several species of Pseudomonas that produce secondary metabolites, mobilize nutrients, and promote plant growth have been reported from Indian Himalayan region (Kumar et al., 2005; Pandey et al., 2006; Trivedi et al., 2005, Selvakumar et al. 2009).

The bacterial strain used in the present study was isolated from the rhizosphere of Amaranth plant, grown at a high altitude location (2509 $\mathrm{m}$ amsl) that is highly prone to heavy snowfall and intermittent freezethaw cycles. Therefore, it is assumed that the bacterium has naturally adapted to harsh extremities of temperatures and would retain its beneficial plant growth promotion traits when inoculated in similar conditions. The phylogenetic tree constructed, based on the $16 \mathrm{~S}$ rRNA gene sequence, revealed its close identity with Pseudomonas lurida, a Gram negative bacterium, which was first described from the rhizosphere of grasses (Behrendt et al., 2007). Considering the fact that this strain was isolated at $4^{\circ} \mathrm{C}$, and expressed plant growth promoting traits at temperatures ranging from 4 to $30^{\circ} \mathrm{C}$, we would call it a psychrotrophic (coldtolerant) plant growth-promoting bacterium, rather than psychrophilic (cold loving).

TABLE I

Plant growth promotion attributes of Pseudomonas sp. NARs9 (MTCC9002) at different incubation temperatures

\begin{tabular}{lccccc}
\hline $\begin{array}{l}\text { Temperature of } \\
\text { Incubation }\left({ }^{\circ} \mathrm{C}\right)\end{array}$ & cfu ml $\mathrm{d}^{-1}$ & $\begin{array}{c}\text { IAA production } \\
\left(\mu \mathrm{g} \mathrm{ml} \mathrm{m}^{-1}\right)\end{array}$ & $\begin{array}{c}\text { Phosphate } \\
\text { solubilization }\left(\mu \mathrm{gl}^{-1} \mathrm{~d}^{-1}\right)\end{array}$ & $\begin{array}{c}\text { Siderophore } \\
\text { Production }\end{array}$ & $\begin{array}{c}\text { HCN } \\
\text { production }\end{array}$ \\
\hline 4 & $5.3 \times 10^{-5}$ & $1.0 \pm 0.002$ & $5.8 \pm 2.10$ & + & - \\
15 & $5.8 \times 10^{-5}$ & $13.1 \pm 0.003$ & $12.7 \pm 1.20$ & ++ & - \\
28 & $9.0 \times 10^{-6}$ & $21.8 \pm 0.002$ & $15.7 \pm 1.82$ & +++ & - \\
\hline
\end{tabular}

Numerical values are mean \pm SD of three independent observations.

IAA: Indole Acetic Acid

None, -; weak, +; moderate, ++; strong, +++

TABLE II

Effect of inoculation of the Pseudomonas sp. NARs9 on growth and nutrient uptake parameters of wheat cultivar VL 829

\begin{tabular}{|c|c|c|}
\hline Parameters & Control & Pseudomonas sp. NARs9 \\
\hline$\%$ Germination & $71.3 \mathrm{a}$ & $85.0 \mathrm{~b}$ \\
\hline Shoot length $(\mathrm{cm})$ & $21.3 \mathrm{a}$ & $27.7 \mathrm{~b}$ \\
\hline Root Length (cm) & $17.0 \mathrm{a}$ & $20.9 b$ \\
\hline Shoot dry weight (g) & $0.045 \mathrm{a}$ & $0.054 \mathrm{~b}$ \\
\hline Root dry weight (g) & $0.060 \mathrm{a}$ & $0.093 \mathrm{~b}$ \\
\hline Chlorophyll a content ( $\mathrm{mg}$ chl a $\mathrm{gfw}^{-1}$ ) & $0.188 \mathrm{a}$ & $0.217 \mathrm{~b}$ \\
\hline Chlorophyll b content ( $\mathrm{mg}$ chl b gfw ${ }^{-1}$ ) & $0.646 \mathrm{a}$ & $0.716 b$ \\
\hline Total Chlorophyll content (mg chl $\mathrm{gfw}^{-1}$ ) & $0.936 \mathrm{a}$ & $1.06 \mathrm{~b}$ \\
\hline Physiologically available Iron content (ppm) & $10.50 \mathrm{a}$ & $12.88 \mathrm{~b}$ \\
\hline Nitrogen $(\mathrm{N})$ uptake ( $\mu \mathrm{g} \mathrm{mg}^{-1}$ plant biomass) & $0.513 \mathrm{a}$ & $0.574 \mathrm{~b}$ \\
\hline Phosphorus (P) uptake ( $\mu \mathrm{g} \mathrm{mg}^{-1-}$ plant biomass) & $0.119 \mathrm{a}$ & $0.144 \mathrm{~b}$ \\
\hline Potassium $(\mathrm{K})$ uptake ( $\mu \mathrm{g} \mathrm{mg}^{-1}$ plant biomass) & $1.61 \mathrm{a}$ & $2.13 b$ \\
\hline
\end{tabular}

All values are the means of ten replications;

Values followed by different letters within a row indicates significant difference $(\mathrm{P}>0.05)$ 
Among the PGP traits, IAA production by the bacterium has a cascading effect on the plant development due to its ability to influence root growth, which in turn affects nutrient uptake and ultimately plant productivity. But the available studies suggest that IAA production is higher in the mesophilic range compared to the cold temperatures (Selvakumar et al., 2008). Though the results of the present investigation are in accordance with earlier recorded observations, IAA production is proposed as a major means of achieving plant growth promotion by the bacterium described in the present investigation. Solubilization of insoluble phosphorous compounds in the rhizosphere by microorganisms is another important means of achieving plant growth promotion (Mehta and Nautiyal, 2001). Since the bacterium was able to solubilize appreciable levels of phosphate under in vitro conditions, it is hypothesized that the $\mathrm{P}$ solubilizing abilities of the bacterium have contributed to the observed plant growth promotion phenomena. This hypothesis finds support in the increased levels $(21 \%)$ of $\mathrm{P}$ uptake in inoculated plants compared to un-inoculated controls (0.119 $\mu \mathrm{g} \mathrm{mg}^{-1-}$ plant biomass) (Table II).

Iron, the fourth most abundant element in the earth's crust, is largely required by all living organisms for direct microbial assimilation. In aqueous solution, iron can exist in either the ferrous $\left(\mathrm{Fe}^{2+}\right)$ or $\left(\mathrm{Fe}^{3+}\right)$ forms, the latter being the less soluble. However, in highly oxidized and aerated soils, the predominant form of iron is the ferric form, which is soluble in water $(\mathrm{pH}$ 7.4) at about $10^{-18} \mathrm{M}$. This is too low to support the growth of microorganisms, which generally need concentrations approaching $10^{-6} \mathrm{M}$ for normal growth (Neilands et al., 1987). Consequently, to survive in such environments, organisms secrete iron-binding ligands (siderophores) that can bind ferric iron and make it available to the host microorganisms. The role of such iron chelating siderophores in plant growth promotion is well established (John et al., 1992). Since the strain reported in the present study produced siderophores at mesophilic and cold temperatures, the nature and properties of the siderophores produced by the bacterium itself constitutes a novel researchable issue.

Hill and mountain agro ecosystems are characterized by difficult terrain; inadequate infrastructure, fragile ecosystems and societies entrenched in traditions. Despite low population density, hill farmers face difficulty in producing crops to meet their needs due to difficult terrain, scattered land holdings, severe topsoil erosion and low input application. The application of external inputs in the form of fertilizers, pesticides etc. is very minimal for various reasons, hence by default, hill agriculture largely remains a low external input based production system. In the context of hill agriculture, cold tolerant microbial inoculants are required since a major part of the crop season is characterized by cold temperatures. The bacterial strain reported in this study positively influenced plant growth and increased the nutrient uptake of a major winter crop uptake under suboptimal growth temperatures (mean soil temperature of $18^{\circ} \mathrm{C}$ ), where introduced mesophilic inoculants would have failed. Since the preliminary results look promising, it is proposed that Pseudomonas sp. strain NARs9 (MTCC9002) could be deployed as a bioinoculant to attain the desired results of bacterization in the hill and mountain agro-ecosystem of the N.W. Indian Himalayas.

\section{ACKNOWLEDGEMENTS}

This study was supported by ICAR network project "Application of Microorganisms in Agriculture and Allied Sectors". Dr. Lakshmi Kant, V. I. H. A., Almora, Uttarakhand is acknowledged for providing the seed material used in this study. Thanks are due to Mr. Sanjay Kumar for his technical assistance in analysis of plant and soil samples.

\section{REFERENCES}

BAKKER AW, SCHIPPER B (1987) Microbial cyanide production and Pseudomonas sp. mediated plant growth stimulation. Soil Biol Biochem 19: 451-457 
BEHRENDT UNDINE, ANDREAS ULRICH, PETER SCHUMANN, JEAN-MARIE MEYER, CATHRIN SPROER (2007) Pseudomonas lurida sp. nov., a fluorescent species associated with the phyllosphere of grasses. Inter J Syst Evol Microbiol 57: 979-985

BROUGHTON WJ, DILWORTH MJ (1971) Control of leghaemoglobin synthesis in snake beans. Biochem $\mathrm{J}$ 125: $1075-1080$

COMPANT S, DUFFY B, NOWAK J, CLEMENT C, BARKA EA (2005) Use of Plant growth-promoting bacteria for biocontrol of plant diseases: principles, mechanisms of action, and future prospects. Appl Environ Microbiol 71: 4951-4959

ELLIOT LF, LYNCH JM (1984) Pseudomonas as a factor in the growth of winter wheat (Triticum aestivum L.). Soil Biochem 16: 69-71

GORDON SA, WEBER RP (1951) Colorimetric estimation of indoleacetic acid. Plant Physiol 26: 192-195

HÄGGBLOM M, MARGESIN R (2005) Microbial life in cold ecosystems. FEMS Microbiol Ecol Thematic Issue 53: $186-188$

HERBRAUD M, POTIER P, (1999). Cold shock response and low temperature Adaptation in Psycrophilic Bacteria. J Mol Microbiol Biotechnol. 1: 211-219

HOLT JG, KREIG NR, SNEATH PHA, STANLEY JT, WILLIAMS ST (1994) Bergey's manual of determinative bacteriology. Williams and Wilkins, Baltimore, MD

JACKSON ML (1973) Soil chemical analysis. New Delhi: Prentice Hall of India Pvt Ltd. pp: 25-214

JOHN MORRIS, DANIEL J, SULLIVAN O, MARGAT KOSTER, JOHN LEONG, PETRE J, FERGAL WESBEEK, GARA O (1992) Characterization of Fluorescent Siderophore-Mediated Iron uptake in Pseudomonas sp. strain M 114: Evidence for the Existence of an Additional Ferric Siderophore Receptor. Appl Environ Microbiol 58: 630-635

KIMURA M (1980) A simple method for estimating evolutionary rate of base substitutions through comparative studies of nucleotide sequences. J Mol Evol 16: 111-120

KING EO, WARD MK, RANEY DE (1954) Two simple media for the demonstration of pyocyanin and fluorescein. J Lab Clin Med 44: 301-307

KUMAR J, NEGI YK, GERG SK (2005) Cold-tolerant fluorescent Pseudomonas isolates from Garhwal Himalayas as potential plant growth promoting and biocontrol agents in pea. Curr Sci 89: 2151-2156

KUMAR S, TAMURA K, NEI M (2004) MEGA3: Integrated software for Molecular Evolutionary Genetic Analysis and sequence alignment. Brief Bioinform 5: 150-163

MEHTA S, NAUTIYAL CS (2001) An efficient method for qualitative screening of phosphate-solubilizing bacteria. Curr Microbiol 43: 51-56
MISHRA, P.K., S. MISHRA, G. SELVAKUMAR, S.C. BISHT, S. KUNDU, J.K. BISHT AND H.S. GUPTA (2008) Characterization of a psychrotrophic plant growth promoting Pseudomonas PGERs17 (MTCC 9000) isolated from North Western Indian Himalayas. Annals of Microbiology 58 (4): 1-8

MORITA RY (1975) Psycrophilic bateria of microorganism. Bacterial Rev. 39: 144-167

MURPHY JP, RILEY JP (1962) A modified single solution method for the determination of the phosphate in natural waters. Anal Chem Acta 27: 31-36

NEILANDS JB, KONOPKA K, SCHWYN B, COY M, FRANCIS RT, PAW BH, BAGG A (1987) Comparative biochemistry of microbial iron assimilation, In: WINKELMANN G, VAN DER HELM D, NEILANDS JB (eds) Iron transport in microbes, plants and animals. Verlagsgescellschaft mbh, Weinheim, pp: 3-33

PANDEY A, TRIVEDI P, KUMAR B, PALNI LMS (2006) Characterization of a phosphate solubilizing and Antagonistic strain of Pseudomonas putida (Bo) Isolated from a sub-Alpine Location in the central Himalaya. Curr Microbiol 53: 102-107

SAITOU N, NEI M (1987) The neighbour-joining method: a new method for reconstructing phylogenetic trees. Mol Biol Evol 4: 406-425

SCHWYN B, NEILANDS J (1987) Universal chemical assays for the detection and determination of Siderophore. Anal Biochem 160: 47-56

SELVAKUMAR G, JOSHI PIYUSH, NAZIM SEHAR, MISHRA PK, BISHT JK, GUPTA HS (2009) Phosphate solubilization and growth promotion by Pseudomonas fragi CS11RH1 (MTCC 8984) a psychrotolerant bacterium isolated from a high altitude Himalayan rhizosphere. Biologia 64: 239-245

SELVAKUMAR G, KUNDU S, JOSHI PIYUSH, NAZIM SEHAR, GUPTA AD, MISHRA PK, GUPTA HS (2008) Characterization of a cold-tolerant plant growthpromoting bacterium Pantoea dispersa 1A isolated from a sub-alpine soil in the North Western Indian Himalayas. World J Microbiol Biotechnol 24: 955-960

STEEL RGD, TORRIE JH (1980) Principles and Procedures of Statistics. $2^{\text {nd }}$ end. NY, USA: McGraw Hill Book Co. Inc

THOMPSON JD, GIBSON TJ, PLEWNIAK F, JEANMOUGIN F, HIGGINS DG (1997) The CLUSTAL-X windows interface: flexible strategies for multiple sequences alignment aided by quality analysis tools. Nucleic Acids Res 25: 4876-4882

TRIVEDI P, PANDEY A, PALNI LMS (2005) Carrier based preparations of plant growth promoting bacteria suitable for use in the cooler regions. World $\mathrm{J}$ Microbiol Biotechnol 26: 941-945

WHIPPS JM (2001) Microbial interactions and biocontrol in the rhizosphere. J Exp Bot 52: 487-511. 
